\section{Ultra-Processed Foods, Nutrition and Pregnancy: Characteristics of Food Consumption by HIV-Positive Women during Pregnancy}

\section{Clarissa de Oliveira Agostini ${ }^{1,4 *}$, Ester Zoche ${ }^{2,5}$, Rafaela da Silveira Corrêa ${ }^{3,5}$, Eunice Beatriz Martins Chaves ${ }^{1,2}$, Helena von Eye Corleta ${ }^{1,2}$ and Vera Lúcia Bosa ${ }^{1,2,4,5}$}

${ }^{1}$ Universidade Federal do Rio Grande do Sul, Porto Alegre, Rio Grande do Sul, Brazil

${ }^{2}$ Hospital de Clínicas de Porto Alegre, Porto Alegre, Rio Grande do Sul, Brazil

${ }^{3}$ Uniritter -Centro Universitário Ritter dos Reis, Porto Alegre, Brazil

${ }^{4}$ Department of Nutrition, Universidade Federal do Rio Grande do Sul, Porto Alegre, Rio Grande do Sul, Brazil

${ }^{5}$ Centro de Estudos em Alimentação e Nutrição (CESAN), Hospital de Clínicas de Porto Alegre, Brazil

This article aims to provide a commentary on the article "Contribution of Ultra-processed Food to the Daily Food Intake of HIV-positive and HIV-Negative Women during Pregnancy". Pregnancy causes physiological changes in the woman's body, modifying her nutritional needs, as well as food intake. If the supply of macro and micronutrients is inadequate, there may be competition between the mother and the fetus, limiting the availability of the necessary nutrients for the proper growth of the fetus [1,2]. Women with HIV have increased energy and nutritional needs during pregnancy and inadequate dietary intake, deficient in micronutrients and macronutrients, could increase the risk of the disease's vertical transmission and progression, increase the chance of opportunistic infections and affect the effectiveness of antiretroviral drugs $[3,4]$.

${ }^{*}$ Corresponding author: Clarissa de Oliveira Agostini, Universidade Federal do Rio Grande do Sul, Porto Alegre, Rio Grande do Sul, Brazil, Tel: +55 51998812604; E-mail: clarissaagostini@hotmail.com

Citation: Agostini CO, Zoche E, Corrêa RS, Chaves EBM, Corleta HE, et al (2021) Ultra-Processed Foods, Nutrition and Pregnancy: Characteristics of Food Consumption by HIV-Positive Women during Pregnancy. J Reprod Med Gynecol Obstet 6: 072.

Received: March 17, 2021; Accepted: March 26, 2021; Published: April 02, 2021

Copyright: (C) 2021 Agostini CO, et al. This is an open-access article distributed under the terms of the Creative Commons Attribution License, which permits unrestricted use, distribution, and reproduction in any medium, provided the original author and source are credited.
In the article, the authors aim to assess the daily dietary intake and the contribution of ultra-processed foods to positive and negative HIV women during pregnancy. Ultra-processed foods are industrial formulations made entirely or, for the most part, from food substances (oils, fats, sugar, proteins), derived from food constituents (hydrogenated fats, modified starch) or synthesized in the laboratory based on organic materials such as oil and coal (dyes, flavorings, flavor enhancers and various types of additives used to provide products with attractive sensory properties) [5]. They have micronutrient deficiencies, as these are found in smaller quantities than those found in fresh or minimal foods processed, this type of food being a nutritional problem of great magnitude worldwide. The consequences caused by micronutrient deficiencies are of great relevance to public health, especially during pregnancy [6].

Our work showed that the calories from the ingestion of ultraprocessed foods corresponded to around $40 \%$ of the daily VET of pregnant women. This high consumption was associated with a lower intake of proteins and fibers and a higher consumption of carbohydrates, trans fats and sodium. HIV positive people consumed less protein, carbohydrates and calcium and more total fats. Our findings reflect the huge increase in the consumption of ultraprocessed foods worldwide. However, their consumption is related to important nutritional deficiencies. The importance of adequate nutrition during pregnancy for adequate fetal development is well established in the literature. Therefore, our findings reinforce the importance of adequate nutrition during pregnancy, especially in this HIV-positive women, in order to avoid unfavorable maternal and fetal outcomes.

\section{References}

1. Bhutta ZA, Das JK, Bahl R, Lawn JE, Salam RA, et al. (2014) Can available interventions end preventable deaths in mothers, newborn babies, and stillbirths, and at what cost? Lancet 384: $347-370$.

2. Goldstein RF, Abell SK, Ranasinha S, Misso M, Boyle JA, et al. (2017) Association of Gestational Weight Gain With Maternal and Infant Outcomes: A Systematic Review and Meta-analysis. JAMA 317: 2207-2225.

3. Mehta S, Manji KP, Young AM, Brown ER, Chasela C, et al. (2008) Nutritional indicators of adverse pregnancy outcomes and mother-to-child transmission of HIV among HIV-infected women. Am J Clin Nutr 87: 1639-1649.

4. Raiten DJ, Grinspoon S, Arpadi S (2005) Nutritional considerations in the use of ART in resource-limited settings. Consultation on Nutrition and HIV/AIDS in Africa: Evidence, lessons and recommendations for action. World Health Organization, Geneva, Switzerland.

5. Ministério da Saúde (2014) Guia alimentar para a população brasileira (2ndedn). Ministério da saúde, Brasília.

6. Louzada MLC, Martins APB, Canella DS, Baraldi LG, Levy RB, et al. (2015) Alimentos ultraprocessados e perfil nutricional da dieta no Brasil. Rev Saúde Pública 49: 38. 


\section{di \\ Hetario}

Advances In Industrial Biotechnology | ISSN: 2639-5665

Advances In Microbiology Research | ISSN: 2689-694X

Archives Of Surgery And Surgical Education | ISSN: 2689-3126

Archives Of Urology

Archives Of Zoological Studies | ISSN: 2640-7779

Current Trends Medical And Biological Engineering

International Journal Of Case Reports And Therapeutic Studies | ISSN: 2689-310X

Journal Of Addiction \& Addictive Disorders | ISSN: 2578-7276

Journal Of Agronomy \& Agricultural Science | ISSN: 2689-8292

Journal Of AIDS Clinical Research \& STDs | ISSN: 2572-7370

Journal Of Alcoholism Drug Abuse \& Substance Dependence | ISSN: 2572-9594

Journal Of Allergy Disorders \& Therapy | ISSN: 2470-749X

Journal Of Alternative Complementary \& Integrative Medicine | ISSN: 2470-7562

Journal Of Alzheimers \& Neurodegenerative Diseases | ISSN: 2572-9608

Journal Of Anesthesia \& Clinical Care | ISSN: 2378-8879

Journal Of Angiology \& Vascular Surgery | ISSN: 2572-7397

Journal Of Animal Research \& Veterinary Science | ISSN: 2639-3751

Journal Of Aquaculture \& Fisheries | ISSN: 2576-5523

Journal Of Atmospheric \& Earth Sciences | ISSN: 2689-8780

Journal Of Biotech Research \& Biochemistry

Journal Of Brain \& Neuroscience Research

Journal Of Cancer Biology \& Treatment | ISSN: 2470-7546

Journal Of Cardiology Study \& Research | ISSN: 2640-768X

Journal Of Cell Biology \& Cell Metabolism | ISSN: 2381-1943

Journal Of Clinical Dermatology \& Therapy | ISSN: 2378-8771

Journal Of Clinical Immunology \& Immunotherapy | ISSN: 2378-8844

Journal Of Clinical Studies \& Medical Case Reports | ISSN: 2378-8801

Journal Of Community Medicine \& Public Health Care | ISSN: 2381-1978

Journal Of Cytology \& Tissue Biology | ISSN: 2378-9107

Journal Of Dairy Research \& Technology | ISSN: 2688-9315

Journal Of Dentistry Oral Health \& Cosmesis | ISSN: 2473-6783

Journal Of Diabetes \& Metabolic Disorders | ISSN: 2381-201X

Journal Of Emergency Medicine Trauma \& Surgical Care | ISSN: 2378-8798

Journal Of Environmental Science Current Research | ISSN: 2643-5020

Journal Of Food Science \& Nutrition | ISSN: 2470-1076

Journal Of Forensic Legal \& Investigative Sciences | ISSN: 2473-733X

Journal Of Gastroenterology \& Hepatology Research | ISSN: 2574-2566
Journal Of Genetics \& Genomic Sciences | ISSN: 2574-2485

Journal Of Gerontology \& Geriatric Medicine | ISSN: 2381-8662

Journal Of Hematology Blood Transfusion \& Disorders | ISSN: 2572-2999

Journal Of Hospice \& Palliative Medical Care

Journal Of Human Endocrinology | ISSN: 2572-9640

Journal Of Infectious \& Non Infectious Diseases | ISSN: 2381-8654

Journal Of Internal Medicine \& Primary Healthcare | ISSN: 2574-2493

Journal Of Light \& Laser Current Trends

Journal Of Medicine Study \& Research | ISSN: 2639-5657

Journal Of Modern Chemical Sciences

Journal Of Nanotechnology Nanomedicine \& Nanobiotechnology | ISSN: 2381-2044

Journal Of Neonatology \& Clinical Pediatrics | ISSN: 2378-878X

Journal Of Nephrology \& Renal Therapy | ISSN: 2473-7313

Journal Of Non Invasive Vascular Investigation | ISSN: 2572-7400

Journal Of Nuclear Medicine Radiology \& Radiation Therapy | ISSN: 2572-7419

Journal Of Obesity \& Weight Loss | ISSN: 2473-7372

Journal Of Ophthalmology \& Clinical Research | ISSN: 2378-8887

Journal Of Orthopedic Research \& Physiotherapy | ISSN: 2381-2052

Journal Of Otolaryngology Head \& Neck Surgery | ISSN: 2573-010X

Journal Of Pathology Clinical \& Medical Research

Journal Of Pharmacology Pharmaceutics \& Pharmacovigilance | ISSN: 2639-5649

Journal Of Physical Medicine Rehabilitation \& Disabilities | ISSN: 2381-8670

Journal Of Plant Science Current Research | ISSN: 2639-3743

Journal Of Practical \& Professional Nursing | ISSN: 2639-5681

Journal Of Protein Research \& Bioinformatics

Journal Of Psychiatry Depression \& Anxiety | ISSN: 2573-0150

Journal Of Pulmonary Medicine \& Respiratory Research | ISSN: 2573-0177

Journal Of Reproductive Medicine Gynaecology \& Obstetrics | ISSN: 2574-2574

Journal Of Stem Cells Research Development \& Therapy | ISSN: 2381-2060

Journal Of Surgery Current Trends \& Innovations | ISSN: 2578-7284

Journal Of Toxicology Current Research | ISSN: 2639-3735

Journal Of Translational Science And Research

Journal Of Vaccines Research \& Vaccination | ISSN: 2573-0193

Journal Of Virology \& Antivirals

Sports Medicine And Injury Care Journal | ISSN: 2689-8829

Trends In Anatomy \& Physiology | ISSN: 2640-7752

Submit Your Manuscript: https://www.heraldopenaccess.us/submit-manuscript 